\title{
The entry strategies of research-based firms in the transition to a sustainable energy system
}

\author{
Margarida Fontes* \\ LNEG - Laboratório Nacional de Energia e Geologia, \\ Campus do Lumiar, Estrada do Paco do Lumiar, \\ Lisboa, 1649-038, Portugal \\ Email: margarida.fontes@lneg.pt \\ ${ }^{*}$ Corresponding author
}

\section{Cristina Sousa}

Univ Portucalense,

Research on Economics, Management

and Information Technologies - REMIT,

Porto, 4200-072, Portugal

and

Instituto Universitário de Lisboa (ISCTE-IUL),

DINAMIA'CET-IUL,

Lisboa, 1649-026, Portugal

Email: cristina.sousa@iscte.pt

\begin{abstract}
The paper discusses the entry strategies adopted by research-based firms introducing advanced renewable energy technologies (RET) in the electricity production sector and their interactions with regime incumbents. Drawing on the sustainability transitions and the strategic management of technology literatures we build an analytical framework and apply it, in an exploratory way, to firms operating in two very diverse energy niches - wind and wave energy - using in depth-case studies. The results suggest that new entrants tend to depend on complementary assets possessed by incumbents, but have conditions to protect their technologies from expropriation; and that the technologies are relevant for (at least some) incumbents, which show interest on them, or are directly involved in their development/use. This is, in most cases, conducive to 'cooperation' strategies, which assume different forms according to the stage of development of the technology and its proximity to incumbents' competences and assets.
\end{abstract}

Keywords: research-based firms; entry strategies; sustainability transitions; RET; renewable energy technologies; niche regime interaction; new entrants; incumbents; disruptive innovation; commercialisation strategy; complementary assets; actor behaviour; case studies.

Reference to this paper should be made as follows: Fontes, M. and Sousa, C. (2017) 'The entry strategies of research-based firms in the transition to a sustainable energy system', Int. J. Technoentrepreneurship, Vol. 3, No. 4, pp.310-329. 